\title{
Nagyszülők és unokák egy háztartásban Háromgenerációs együttélések Magyarországon
}

\author{
Monostori Judit ${ }^{1}$ \\ https://doi.org/10.51624/SzocSzemle.2021.1.5 \\ Beérkezés: 2020. 12. 30. \\ Átdolgozott változat beérkezése: 2021. 04. 23. \\ Elfogadás: 2021. 05. 03.
}

\begin{abstract}
Összefoglaló: A tanulmány a háromgenerációs együttélésekkel foglalkozik. Azokkal a háztartásokkal, ahol unokák, szülők és nagyszülók élnek egy fedél alatt. Noha kétségkívül viszonylag ritka, és hosszabb távon csökkenő tendenciát mutató együttélési formának tekinthetjük ezt, számításaink szerint napjainkban Magyarországon körülbelül 560 ezer ember él ilyen háztartásban. Társadalmon belüli arányukat egy ország általános jóléti szintje, a társadalompolitikák, a generációk közötti szolidaritás erőssége és mintázatai, a népesség demográfiai struktúrája, a generációs együttélések történelmi gyökerei és az ezzel kapcsolatos attitüdök is befolyásolják. Az általunk vizsgált 1980 és 2016 közötti időszakban összességében csökkent, de az 1990-es években növekvő trendet mutatott a háromgenerációs háztartások előfordulása. Időben a társadalmi hátrányok egyre inkább összekapcsolódtak ezzel az együttélési formával: az alacsony iskolai végzettségú szülők körében ugyanis a csökkenés korántsem volt olyan mértékú, mint a magasabban kvalifikáltabbak körében. Az 1990-es években, a gazdasági recesszió évei alatt pedig az átlagosnál sokkal jelentősebb növekedést láthatunk köreikben. Szorosan kapcsolódik ezt a háztartási forma az egyszülős családokhoz is. Ennek főként az az oka, hogy válás után a gyermekes szülök egy része visszaköltözik a szülői házba. Ez is jelzi, hogy az együttélési formák az életpálya során változnak, a háromgenerációs együttélés is bizonyos életszakaszokra (családalapítás környéke, válás utáni életszakasz, gondozást igénylő időskor) jellemzőbb, mint más életpályaszakaszra.
\end{abstract}

Kulcsszavak: háromgenerációs háztartások, gyermekes családok, nagyszülők, unokák

\section{Bevezetés}

Európa bizonyos térségeiben és meghatározott társadalmi csoportokban hosszú évszázadokon keresztül a legtermészetesebb együttélési formának számított, ha három generáció is élt egy háztartásban. ${ }^{2} \mathrm{Az}$ idősebbeknek éppúgy megvolt a háztartáson belüli szerepe, mint az aktív korú generációnak vagy éppen a legfiatalabbaknak, a gyerekeknek. A paraszti társadalmakban az együttélés alapját leginkább a közös gazdaság jelentette, amely a háztartástagok szoros munkamegosztásán ala-

1 Népességtudományi Kutatóintézet, email: monostori@demografia.hu

2 Tanulmányunkban a háromgenerációs háztartás szinonimájaként használjuk a nemzetközi irodalomban elterjedt multigenerációs háztartás fogalmát, illetve ugyanezzel a tartalommal használjuk a nagyszülős háztartás kifejezést is. 
pult. Amint a háztartás mint gazdálkodó egység kezdte elveszíteni az erejét, úgy egyre elterjedtebbé válnak a nukleáris családok, amelyekben jellemzően csak egy vagy két generáció él együtt. Ugyanakkor azt is látni kell, hogy a multigenerációs háztartások aránya sohasem volt olyan magas, mint azt gondolnánk. Erre elsőként Laslett (Laslett 1965, 1966; Laslett-Wall 1972) mutatott rá az 1960-as évektől induló kutatásaiban, az iparosodás előtti Anglia adatait tanulmányozva. Megállapította, hogy az angol társadalmat már az iparosodás előtti időkben is a nukleáris család dominanciája jellemezte. Ennek egyszerűen az volt az oka, hogy a várható élettartam sokkal alacsonyabb volt, mint napjainkban, így a nagyszülők ritkán érték meg unokáik felnőtté válását. A társadalmak életkori struktúrája tehát erősen korlátozta a háromgenerációs háztartások elterjedését. Ruggles ehhez azt is hozzáteszi, hogy a magas fertilitás más vonatkozásban is akadályozta a multigenerációs háztartások dominanciájának kialakulását. Nevezetesen, hogy az idősek jellemzően csak az egyik gyerekük családjával éltek együtt, a többi gyereknek új, önálló háztartást kellett alkotnia. Így a származási családból - a magasabb termékenység révén - több új, különélő nukleáris család jött létre, mint napjainkban (Ruggles 2003).

Azt is előre kell bocsátani, hogy pusztán a háztartásszerkezeti kérdések vizsgálata nem ad képet ezeknek a háztartásoknak a tényleges múködéséről, mindazokról az előnyökről és hátrányokról, amelyek ehhez az együttélési formához kapcsolódhatnak. Nem tudjuk például azt, hogy hol vannak a háztartás irányításának súlypontjai, a háztartáson belül kinek a szükségletei motiválják jobban ezt az együttélési formát. Ezek persze lehetnek egyéni sajátosságok is, de feltételezhetően a múltban és jelenleg is vannak ebben társadalmi mintázatok. A múltbéli példát Magyarország 18. század közepi időszakából hozzuk, amikor is megfigyelték, hogy a német falvakban a háztartásfők fiatalabbak, mint például a magyar vagy a horvát többségú településeken. Ennek az volt az oka, hogy a német közösségekben élt az ún. visszavonulás szokása, azaz az idősödő gazda még életében átadta az irányítást a következő generációnak, így a háztartás irányítása hamarabb a fiatalabbak kezébe került. Ez viszont nem volt szokás a magyar és a horvát közösségekben (Faragó 2011). Szépirodalmi példaként Oravecz Imre leírását említhetjük, aki a 19. század végén egy Észak-Magyarországon élt család példáján mutatja be a háztartáson belüli hatalmi viszonyokat, a munkaszervezés fő jellegzetességeit: „Elborult a tekintete, elcsüggedt. A termékeny izgalmat meddô szorongás váltotta fel. Lehet, hogy nem is megy sehova, nem lesz az egészből semmi. Itt gebed meg, itthon, föld, vagyon nélkül, az apja cselédjeként, így múlik el a fiatalsága. Amikor aztán oda az erö, a kedv, vénségére örököl majd pár holdacskát, amivel akkor már nem megy semmire. Behúzta a nyakát, komoran nézett maga elé. Úzte, hajszolta az agyát, a gondolkodását, hogy kiötöljön valamit." (Oravecz 2020) Mint ez a példa is mutatja, a háromgenerációs együttélési forma sok fiatal számára korábban is inkább kényszert jelentett, és ahogyan elterjedt a tömeges oktatás, az egyéni kereset, és csökkent a fiatalokra irányuló szülői kontrol ereje, úgy a fiatalok mobilabbak lettek, városokba költöztek, és erőteljesebben csökkent a multigenerációs háztartások elterjedtsége is (lásd ezekről: Ruggles 2007; Goldscheider-Lawton 1998). 
Napjainkban is felmerül a kérdés, hogy miért jönnek létre a multigenerációs háztartások, hogy mely generációk szükségletei motiválják azt inkább, és hogy milyen jellegűek ezek a szükségletek. Milyen szerepe van a makroszintű folyamatoknak (például a lakáspiac szúkössége, a gazdasági recesszió, az állami szintű gondozás elégtelen múködése), és milyen a mikroszintűeknek (a szegénység, az alacsony társadalmi státuszú szülőktől származás, és ennek továbbörökítése, a „középső” generáció részéről a párkapcsolatok felbomlása, a korai gyerekvállalás, az idősek felől a kielégítetlen gondozási szükséglet).

Kutatásunkhoz hazai szakirodalmi előzmények szinte alig vannak, aminek részben az az oka, hogy sokan úgy gondolják, ez az együttélési forma már-már kiveszőben van. Noha becsléseink szerint körülbelül 120 ezer ilyen háztartás található napjaink Magyarországán, ahol több mint 560 ezren élnek (saját számítás a 2016-os Mikrocenzus alapján). Ritka kivételnek számít az is, hogy ezekről a háztartásokról statisztikákat olvashatunk (KSH 2005), egyszerűen azért, mert a legfontosabb potenciális adatforrások, a népszámlálások adatgyűjtési és közlési stratégiája nem kezeli kiemelt szempontként, hogy ezekről az együttélési formákról pontosabb képpel rendelkezzünk. Az alkalmazott háztartás-tipológiájukban a háromgenerációs együttélések éppúgy jelen vannak az egycsaládos és a többcsaládos háztartásokban is. Külön kategóriaként általában nem jelennek meg.

Ebben a tanulmányban az utóbbi évtizedek háromgenerációs háztartásaival foglalkozunk a fiatalabb háztartástagok - azaz a szülők és az unokák - szemszögéből. Megvizsgáljuk, hogyan alakult ezeknek a háztartásoknak a száma, és mely társadalmi rétegekre jellemzőek. Korábbi, háztartásszerkezettel és annak változásaival foglalkozó munkák (Harcsa-Monostori 2012; 2018) már részben érintették ezeket a kérdéseket. Ezek hívták fel a figyelmünket arra, hogy bizonyos társadalmi csoportokban - például a gyermeküket egyedül nevelő szülők körében - a háromgenerációs együttélési formák lényegesen meghaladják az átlagos szintet.

Tanulmányunkat azzal kezdjük, hogy áttekintjük, milyen értelmezési keretek között lehet tárgyalni a háromgenerációs együttélési formák létrejöttét. Ezután nemzetközi kitekintéssel folytatjuk, és összegezzük mindazokat a kutatási eredményeket, amelyek ezeknek a háztartásoknak az elterjedtségére, demográfiai és társadalmi jellemzőire vonatkoznak. Majd megvizsgáljuk, hogy az 1980 és 2016 közötti időszakban hogyan alakult a háromgenerációs háztartások aránya, milyen makroszintű jelenségekkel függött ez össze, és milyen demográfiai és szociológiai jellemzők valószínúsítik a kialakulásukat. Hogyan zajlanak ezek a folyamatok a különböző társadalmi csoportokban? Mennyire köthető a háromgenerációs együttélés az alacsonyabb státuszokhoz, elsősorban az alacsonyabb iskolai végzettséghez? Milyen szerepe van a válásnak / a társ elvesztésének abban, hogy kialakuljon vagy fennmaradjon a háromgenerációs háztartás? Ezt követően azzal a kérdéssel foglalkozunk, hogyan keletkeznek és mennyi ideig tartanak ezek az együttélési formák az egyéni életpályán. Vajon napjaink háromgenerációs háztartásairól is elmondható-e, hogy 
többségükben csak az életpálya egy-egy szakaszához kapcsolódnak, amiből a legtöbben viszonylag rövid időn belül kilépnek?

\section{A háromgenerációs háztartások keletkezésének értelmezési keretei}

A háromgenerációs háztartások kialakulása és múködése többféle kontextusban is vizsgálható. Az egyik az intergenerációs transzferáramlás vizsgálati kerete. A generációk közötti transzfereket a kutatások többsége háztartások közötti transzferként közelíti meg, amikor a háztartások közötti pénz, vagyon, gondozási támogatás vagy időtranszfer kutatását helyezi a középpontjába (lásd példaként: Albertini et al. 2007). Ezek a kutatások nagyon gyakran figyelmen kívül hagyják, hogy a háztartásokon belül is zajlik a javak áramlása az egyik generációtól a másik felé. Az, hogy ez milyen mértékű, megszabja a háztartások közötti transzferek alakulását is. Vagyis azokban az országokban, ahol kiterjedt a multigenerációs háztartások aránya, a háztartások közötti transzferek alacsonyabb szintje nem feltétlenül jelenti azt, hogy a generációk közötti transzferáramlás kevésbé kiterjedt, mint azokban, ahol a háztartások közötti transzferek magasabbak, de sokkal kisebb a háromgenerációs háztartások aránya. Ezek az együttélési formák a javak generációk közötti átcsoportosításának közvetlen keretét adják, amelyben anyagi, lakhatási, gondozási és egyéb transzferek áramolnak a három generáció között.

Az, hogy az egyes generációk különböző szükségletei hogyan elégülnek ki, az makrogazdasági tényezőktől, az adott jóléti állam preferenciáitól és kiterjedtségétől is függ. Több nemzetközi kutatás is utalt arra, hogy a gazdasági recessziók időszakában megnövekedett a multigenerációs háztartások aránya (Pew Research Center 2010; 2011). Ehhez a lakhatási problémák és a munkaerőpiaci nehézségek járultak hozzá, amelyek elsősorban a „középső”, vagyis a szülői generáció részéről jelentkeztek. Emellett a jóléti állam kiterjedtsége és preferenciái is befolyásolják, hogy milyen erősek a „külső kényszerek” arra, hogy a generációk egy háztartásba(n) éljenek/költözzenek. A nagyszülői generáció szempontjából két fontos kérdés merül fel. Az egyik, hogy mennyire kiterjedt és milyen színvonalú ellátást biztosít egy adott ország nyugdíjrendszere, a másik pedig, hogy mennyire kiterjedt a gondozási szempontból rászoruló idősek állami támogatása. Ha a nyugdíjrendszer nem teljes körű, és/vagy alacsony ellátást nyújt, ha a gondozási feladatokat az állam alapvetően a családokra hárítja, vagy erősen szelektál a gondozásra szorulók között, és/vagy magas térítési díjakat szab meg, akkor a háromgenerációs együttélések aránya növekedhet, hiszen lesznek családok, amelyek csak ilyen módon tudják támogatásra/ gondozásra szoruló idős családtagjaikat ellátni (lásd ezekről például Bianchi et al. 2007; McGarry-Schoeni 2000; Hareven 1994).

Makroszintű összefüggéseket keresve kiemelhetjük a kulturális tényezők szerepét is. Ez azt jelenti, hogy a társadalmak abban is különböznek egymástól, hogy ho- 
gyan múködnek a családi kohézió, a családi szolidaritás elemei, mennyire tartanak össze a családok, mennyire érzik kötelességüknek a rászoruló családtagok, gyermekek, unokák, más oldalról az idős szülők és nagyszülők támogatását. Ezek szintén meghatározhatják a háromgenerációs háztartások előfordulását (Coleman-Ganong 2008; Bengtson et al. 2000; Piercy 1998).

Az életciklus-elméletek felől megközelítve a kérdést, a háztartásra úgy tekinthetünk, mint dinamikusan változó együttélési formára, amelynek keretei folyamatosan változnak. Nemcsak abban az értelemben, hogy újabb háztartástagok születnek és halnak meg, hanem abban is, hogy az egyén életpályája során több családban/ háztartásban éli az életét. Egy-egy együttélési forma hosszabb, míg mások rövidebb ideig tartanak az egyéni életútban. Az együttélési formák változását demográfiai események (születés, halál, házasságkötés, válás) és egyéni/családi élethelyzetek (szegénység, betegség) is befolyásolják. Erre mutat rá Ruggles azon munkája, amely a 19. századi amerikai háztartásokat vizsgálja. Megállapítja, hogy a vizsgált időszakban a háromgenerációs háztartás szinte minden egyéni életpályának része volt, de általában viszonylag rövid ideig tartott (Ruggles 2003). Időskorban viszont nagyon meghatározó volt a szerepe, hiszen a társadalombiztosítási rendszer hiánya vagy rendkívüli szúkössége miatt az időseknek ez az együttélési forma nyújtotta az időskori biztonságot. Hasonló következtetésre jutott Andorka is, amikor azt állapította meg, hogy a kiterjesztett és többcsaládos háztartások aránya azokban a korosztályokban volt a legmagasabb, amelyeknek a háztartásában a fiatalok éppen új családot alapítottak, és még nem költöztek el a szülőktől (Andorka 1996).

Az utóbbi évtizedek kutatásainak többsége azt mutatja, hogy az intergenerációs transzferek jelentős része a középkorú generációktól áramlik a gyerekek felé, illetve az idősektől a középgenerációk és a gyerekek felé. Az idősek jórészt csak az életük legvégén kapnak transzfereket a fiatalabbaktól, aminek egyik formája, hogy a gondozásra szoruló idősek gyerekeik háztartásába költöznek (Liang et al. 2005; Choi 2003; Hays 2002; Mickus et al. 1997). A középkorú és az idős generációk együttélését főként a középkorú generációk olyan életeseményei váltják ki, mint például a munkahely elvesztése és a válás (Ward et al. 1992; 2007; Choi 2003; Aquilino 1990).

A különböző értelmezési keretek különböző magyarázatokat adhatnak a háromgenerációs együttélések létrejötte, demográfiai és szociológiai profilja vonatkozásában, de nyilvánvaló, hogy egyszerre több tényezőnek is szerepe van a folyamatokban. A hatásokat szétválasztani és pontosan számszerúsíteni lehetetlen, de fontos gondolati támpontokat jelenthetnek a megértésben, amelyeket az elemzésünkben igyekeztünk figyelembe venni. 


\section{Háromgenerációs háztartások Európában és az Egyesült Államokban}

A háromgenerációs háztartások aránya a korábbi évszázadokban is jelentős térbeli különbségeket mutatott, amire már Laslett is rávilágított (1983). Európán belül a déli, keleti és közép-kelet-európai országokban volt ez a leginkább elterjedt együttélési forma, de egy-egy országon belül is nagy különbségeket mértek etnokulturális csoportok, a lakóhely jellege és társadalmi státuszok szerint is (Faragó 2011; Andorka 1996). Az országok és az egyes társadalmi rétegek közötti különbségekre a jelenkori kutatások is rámutattak (Verbist et al. 2019; Iacovou-Skew 2011). A 2000-es évek végén végzett kutatások alapján, miközben számos észak- és nyugat-európai országban 1-3 százalék körül mozgott azoknak a kiskorú gyermekeknek az aránya, akik nemcsak szüleikkel, hanem nagyszüleikkel is együtt élnek, addig a kelet-európai országokban jellemzően 10 százalék feletti a megfelelő érték. Ezek közül néhányban még a 20 százalékot is meghaladja, kiugróan magas például Bulgáriában (1. ábra). $\mathrm{Az}$ országok közötti különbségek megértésére többféle magyarázat is született, és ezzel vissza is utalunk az imént bemutatott értelmezési keretekre. Az interpretációk között ugyanis nagy hangsúlyt kapott az egyes országok általános gazdasági helyzetének, a kulturális kontextusnak és a jóléti politikáknak a differenciáló ereje (Glaser et al. 2018; Preoteasa et al. 2018). A jóléti politikák vonatkozásában többen is Saraceno és Keck tipológiájához nyúlnak vissza, amely a generációk közötti informális együttmúködés alakulását arra vezeti vissza, hogy az állam mit és milyen arányban vállal fel a gyermekekre és az idősekre irányuló gondozási tevékenységben. Eszerint azokban az országokban, ahol a gondozási tevékenység alapvetően az állam által koordinált, állami szolgáltatásokra épülő rendszer keretei között zajlik, a generációk közötti informális transzfer-áramlás gyengébb. Ebből következik az is, hogy a háromgenerációs háztartások elterjedtsége is a defamiliarizációs politikát folytató államokban alacsonyabb. Így például a skandináv országokban. Ez a megközelítés viszont nem igazán ad támpontot annak megértésére, hogy a dél-európai országokban mivel magyarázható a háromgenerációs háztartások ugyancsak alacsony szintje, amely a skandináv és a nyugat-európai országokhoz képest ugyan magasabb, de összességében mégis rendkívül alacsonynak tekinthető. És nem ad magyarázatot arra sem, hogy a kelet-európai országokban miért ennyivel elterjedtebbek ezek az együttélési formák. Mindezek alapján sokkal inkább azt feltételezhetjük, hogy egy ország általános jóléti szintje és a kulturális tényezők a jóléti politikáknál is fontosabb szerepet játszanak. 
2008

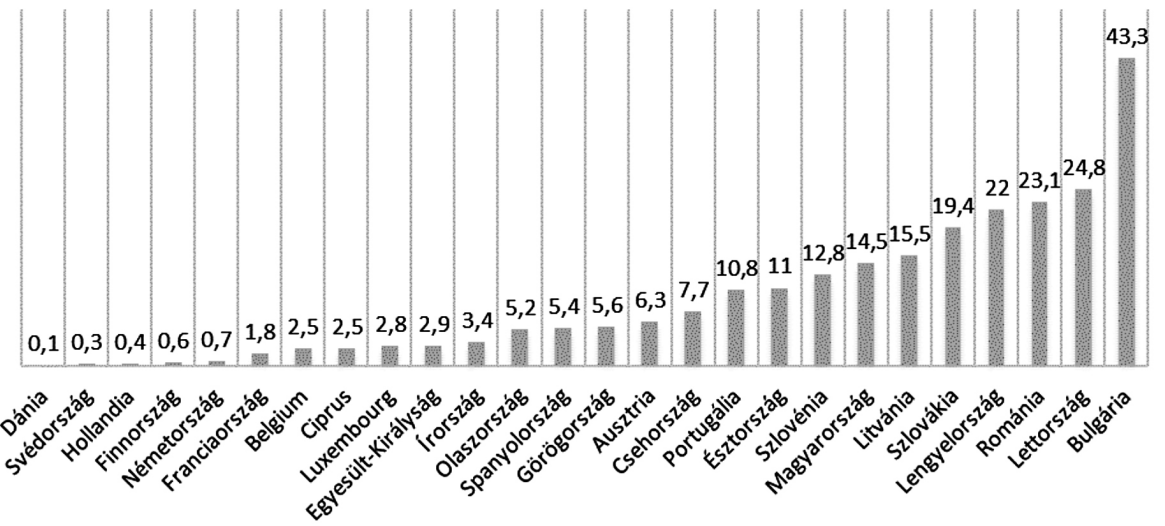

Forrás: Iacovou-Skew 2011

A háromgenerációs együttélési formák elterjedtségének megértésében fontos támpontot adhat az időbeli tendenciák vizsgálata. Az időbeli trendek és a lehetséges magyarázó tényezők változásainak egyidejű követése rámutathat arra, hogy makroszinten melyik tényező befolyásolja erőteljesebben a multigenerációs háztartások kialakulását. Viszont éppen azért, mert a nyugat-európai országok többségében a háromgenerációs háztartások aránya rendkívül alacsony, nagyon kevés kutatás foglalkozik azzal, hogy hogyan változott ezeknek az együttélési formáknak az elterjedtsége, és mi jellemzi őket. A kutatások korlátjaként jelenik meg az is, hogy nincsenek nemzetközileg összehasonlítható adatbázisok, amelyek a változás trendjeinek bemutatására alkalmasak lennének. A háromgenerációs háztartások aránya csak becslésként értelmezhető a népszámlálási adatok esetében is, hiszen a háztartásban élők rokoni kapcsolatának vizsgálatakor általában nem rögzítik a nagyszülő és az unoka státuszt. Ilyen becslést alkalmazott az a kutatás is, amely öt európai országban (Ausztria, Franciaország, Görögország, Portugália) és az Egyesült Államokban vizsgálta az 1980 és 2010 közötti trendeket (Glaser et al. 2018). Az IPUMS népszámlálási adatait használva a szerzők bizonyos rokonsági láncok és életkori adatok felhasználásával következtetnek arra, hogy az adott háztartás háromgenerációs-e, vagy sem. Az USA-ra vonatkozó korábbi kutatások eredményei és az interpretációk alapján a trendek alakulását egyéni és társadalmi szintű változásokkal is magyarázzák. Előzetes várakozásaik szerint azokban az országokban, ahol az állam egyre inkább kivonult a gondozás feladatából, mint például Románia, Görögország vagy Portugália esetében, a háromgenerációs háztartások arányának növekednie kellene. Várakozásaikat azonban csak a romániai tendenciák erősítették meg. Portugália vonatkozásában egyébként ezek az eredmények összhangban vannak azokkal a ku- 
tatási eredményekkel, amelyek a háromgenerációs háztartások arányának hosszú távú csökkenését mutatták ki. Ezek szerint Portugáliában 1960 és 2001 között 15ről 10 százalékra csökkent ezeknek az együttélési formáknak az aránya az összes háztartáson belül (Vasconcelos 2003; Wall 2004).

Rövidebb időszakokat tekintve viszont több európai országban is mérték már a háromgenerációs háztartások növekvő arányát. Portugáliában például az 1994 és 2001 közötti időszakban (Albuquerque 2009), az Egyesült Királyságban 1991 és 2001 között (Nandy et al. 2011), Szlovákiában és Lengyelországban pedig 2007 és 2017 között (Eurofound 2019). Ezek a változások viszonylag kisebb mértékúek voltak, és a kutatásoknak nem sikerült olyan makroszintű tényezőket beazonosítaniuk, amelyek egyértelműen és azonos irányba befolyásolták volna a multigenerációs háztartások elterjedtségét.

Más a helyzet az individuális jellemzők vonatkozásában. Az ezt kutató nemzetközi vizsgálatok több, országokon átívelő, hasonló mintázatot találtak. Ilyen volt például, hogy az európai országok többségében ezekben a háztartásokban a nagymamákkal való együttélés jellemzőbb volt, mint a nagypapákkal való együttélés. Különösen azokban az országokban nagy a nemek szerinti különbség, ahol a háromgenerációs együttélési forma általában véve elterjedtebb (Verbist et al. 2019). Ezek jellemzően azok, ahol a férfiak és a nők várható élettartama közötti különbség nagyobb, és a nők nagyobb arányban élnek partner nélkül. Ugyanakkor Franciaországban és Hollandiában, ahol a háromgenerációs együttélési forma meglehetősen ritka, a nagypapákkal való együttélés a jellemzőbb. Kutatók ezt azzal magyarázzák, hogy a megözvegyült idős férfiak nagyobb részének jelent problémát a mindennapi feladatok megoldása, mint az ugyanilyen helyzetben levő nőknek (ILC 2012), ezért ők nagyobb valószínűséggel költöznek össze a gyermekeikkel, mint az idős nők.

Az európai országok többségében a multigenerációs háztartásban élő idősek nem számoltak be nagyobb mértékben rossz egészségi állapotról, mint a nem ilyen háztartásban élő társaik (Verbist et al. 2019), noha az idősek rossz egészségi állapota, gondozási szükséglete lehetne az egyik fő motivációja a multigenerációs háztartások kialakulásának. Ebből a kutatók azt a következtetést vonták le, hogy napjainkban a multigenerációs együttélések kialakulását nem az idősek, hanem sokkal inkább a fiatal generációk szükségletei motiválják. Erre a következtetésre jutott Verbist és társainak kutatása is, akik azt vizsgálták, hogy a háromgenerációs háztartások jövedelmében mekkora arányt képvisel az idős, és mekkorát a „középső” generáció jövedelme (Verbist et al. 2019). A 2013-as EU-SILC adatokat használták 32 országra kiterjedően. Háromgenerációs háztartásnak azokat tekintették, amelyben legalább egy 18 év alatti, egy 18 és 64 év közötti és egy 64 év feletti háztartástag élt. Megállapították, hogy a transzferáramlás iránya ezekben az országokban alapvetően a gyermekes családok felé irányult az idősebb generáció felől. Azaz a gyermekes családok jövedelmi helyzetét javította az a tény, hogy a nagyszülők is a háztartásban éltek. Sőt a kelet-európai or- 
szágok többségében azt találták, hogy a háromgenerációs háztartásban élő gyermekek anyagi helyzete még valamivel jobb is volt, mint a kétgenerációs háztartásban élőké.

A fiatalabb generációk, azaz a gyermekes családok felől nézve több kutatás is kimutatta, hogy a szülők válása szignifikánsan növeli a multigenerációs háztartások kialakulásának kockázatát. Ezzel magyarázható, hogy az egyszülős családok nagyobb arányban élnek együtt a nagyszülőkkel, mint a párkapcsolatban élők (CohenCasper 2002; Boaz et al. 1999). Életpálya adatokat vizsgálva pedig egészen magas lehet az érintett gyermekek aránya. Egy amerikai kutatás szerint például az egyszülős családba születő városi gyermekek 60 százaléka élt legalább egyszer a nagyszüleivel is gyermekkorában (Pilkauskas 2012).

A multigenerációs együttélési forma a legtöbb országban rurális környezethez kapcsolódik (ILC 2012). Ennek valószínúleg több oka is lehet. Az egyik, hogy a falvakban általában kevésbé érhetők el azok a szolgáltatások, amelyek a rászoruló idősek mindennapi szükségleteinek kielégítését szolgálják, és feltételezhetően a gyermekjóléti szolgáltatások is korlátozottabbak. A másik a különböző településtípusokon levő házak/lakások eltérő adottságaival függ össze. A falvakban általában nagyobb alapterületű otthonok vannak, ugyanakkor kisebb értéket képviselnek a hasonló nagyságú városiakhoz képest. Az előbbi a lehetőségét teremti meg, hogy három generáció együtt élhessen, utóbbi pedig a fiatalabb generációk szülői házból való elköltözését korlátozza.

A nemzetközi kutatási eredmények áttekintése után megvizsgáljuk, hogy Magyarországon hogyan alakult a háromgenerációs háztartások elterjedtségének trendje, és milyen egyéni/családi tényezők határozzák meg, hogy valaki ilyen háztartásban éljen.

\section{Adatok, módszerek}

A tanulmányban az 1980 és 2011 közötti népszámlálási adatokat, továbbá a 2016os mikrocenzust és az Életünk fordulópontjai adatfelvételt használtuk. Az 1980as, 1990-es, 2001-es és 2011-es népszámlálás vonatkozásában teljes körű adatokat használtunk, míg a 2016-os mikrocenzus mintája a lakosság 10 százalékára terjedt ki. Az Életünk fordulópontjai adatfelvétel egy 2001-ben indított demográfiai panel felvétel, amelynek kezdő mintanagysága megközelítőleg 16 ezer volt, amely mintapótlással az 5. hullám végére közel 9300-ra csökkent. Tanulmányunkban alapvetően azokkal a háromgenerációs háztartásokkal foglalkoztunk, ahol a legfiatalabb generáció legalább egy tagja 0 és 24 év közötti gyermek státuszban levő háztartástag. Ennek alapvetően két oka van: az egyik, hogy így próbáltuk homogenizálni a vizsgált csoportot, a másik pedig az, hogy így tudunk közvetlenül is kapcsolódni azokhoz a korábbi kutatásokhoz, amelyek család- és háztartásszerkezeti kérdéseket vizsgáltak, és így definiálták a gyermek fogalmát. Továbbá az is szempont volt, hogy 
ezzel a megközelítéssel a háromgenerációs háztartások túlnyomó többségét (2016ban 84 százalékát) le tudjuk fedni.

1. táblázat: Gyermek státuszban élő személyek a különböző háztartásokban, 2016

\begin{tabular}{|c|c|c|c|c|} 
Gyermekek különböző definíciók szerint & $\begin{array}{c}\text { Kétgenerációs } \\
\text { háztartásban } \\
(\%)\end{array}$ & $\begin{array}{c}\text { Háromgenerációs } \\
\text { háztartásban } \\
(\%)\end{array}$ & $\begin{array}{c}\text { Összesen } \\
\text { (\%) }\end{array}$ & $\mathbf{N}$ \\
\hline Gyermekek életkori határ nélkül & 92,1 & 7,9 & 100,0 & 2884622 \\
\hline 0 és 24 év közötti gyermekek & 91,2 & 8,8 & 100,0 & 2189409 \\
\hline 25 éves és idősebb gyerekek & 94,7 & 5,3 & 100,0 & 695213 \\
\hline
\end{tabular}

Forrás: Mikrocenzus 2016. Saját számítás

Megjegyzés: A népszámlálásokban gyermeknek tekintenek mindenkit, aki legalább egy szülöjével együtt él, és nincs „önálló családja”, azaz nincs együtt élô partnere és/vagy gyermeke. A gyermek definíciójának nem kritériuma, hogy a szülőnek a gyermek vér szerinti gyermeke legyen. Ilyen módon számolni tudtunk azokkal a gyermekekkel is, akiket a szülök örökbe fogadtak, vagy hivatalos örökbefogadási procedúra nélkül gyermeküknek tekintenek.

A népszámlálások és a mikrocenzus legnagyobb előnye, hogy a viszonylag ritkán előforduló háztartástípusok vizsgálatára is alkalmas, ezért választottuk empirikus adatbázisként a háromgenerációs háztartások elemzésére is. További fontos szempont volt, hogy a népszámlálások egy hosszabb időszak - csaknem negyven év áttekintésére adnak lehetőséget. Ugyanakkor azt is látni kell, hogy a népszámlálásoknak nem célja a háromgenerációs családokról statisztikákat közölni, és ennek következtében az adatfelvételi koncepciójuk sem fordít figyelmet arra, hogy ez az együttélési forma nagy pontossággal kutatható legyen. Az egycsaládos háztartásokban a nagyszülőket „felmenő rokonként” definiálják, de azt nem tudjuk, hogy nagyszülőről vagy dédszülőről van szó. Tanulmányunkban mi minden felmenő rokont nagyszülőnek tekintettünk, így ezzel a megközelítéssel felülbecsüljük a nagyszülős háztartások arányát, noha úgy gondoljuk, hogy ez a felülbecslés igen kis mértékű. A két- vagy többcsaládos háztartások kategóriájából azokat a háztartásokat próbáltuk megtalálni, ahol a második vagy többedik családban a nagyszülők élnek. A népszámlálási gyakorlat ugyanis azokat a háztartásokat, ahol nemcsak egy, hanem két nagyszülő is a háztartásban él, többcsaládos háztartásnak tekinti, szemben az előbb említett típussal, ahol a gyermekes család, ha egy nagyszülő felmenőként kapcsolódik hozzá, nem alkot önálló családot. A többcsaládos háztartások esetében a nagyszülős háztartások becslése a következőképpen történt: megvizsgáltuk, hogy a háztartásban élő gyermekes család szülői generációja és a másik családban élők generációja között mekkora a korkülönbség. Ha a „középső generáció” legidősebb tagja és a legidősebb generáció legfiatalabb tagja között legalább 16 év különbség volt, akkor nagyszülős háztartásnak tekintettük az adott háztartást. Természetesen ez is a felülbecslés irányába hat, hiszen az is lehetséges, hogy a gyermekes család nagynénik/nagybácsik vagy egyéb idősebb, a tágabb családhoz tartozó rokon családdal alkot közös háztartást. Ez esetben is úgy véljük, hogy kismértékű torzítást jelenthet ez csupán, hiszen már a többcsaládos háztartások előfordulása is nagyon 
ritka, és feltételezhetjük, hogy ezeknek döntő többsége olyan, ahol a nagyszülőkkel élnek együtt a fiatalabb generációk.

Az Életünk fordulópontjai adatfelvételben nincsenek ilyen módszertani problémák, hiszen a háztartás szerkezetét vizsgáló kérdésekből egyértelműen kiderül, kik az unokák, a szülők és a nagyszülők a háztartásban. Hátránya viszont, hogy az adatfelvétel rendkívül gazdag tematikája ellenére az olyan, a társadalomban ritkábban előforduló jelenségek, mint a multigenerációs háztartások kutatása, kevésbé alkalmas, hiszen a mintába ilyen paraméterrel bekerülő háztartások száma viszonylag kicsi (2. táblázat). Ugyanakkor úgy véljük, hogy hasznos lehet ezeknek az adatoknak az elemzése is, hiszen néhány kérdés vizsgálatára csak ez az adatgyüjtés áll rendelkezésre. Ilyen például annak a bemutatása, hogy hogyan keletkeznek ezek a háztartások, milyen élethelyzetekkel kapcsolhatók össze, és mennyire tartósak az életpályán. Az adatfelvétel arra ad lehetőséget, hogy az egyéni életpályákból egy 15 éves szakaszt tekintsünk át. A panelkopás miatt az elemzésünkben nyilván csak azok az egyének szerepelnek, akik mind az öt adatfelvételi évben benne maradtak a mintában. A panelkopást ugyan súlyozással kompenzálni tudjuk egy bizonyos mértékig, de azt nem tudjuk, hogy a minta kopása hogyan érinti az olyan kisebb társadalmi csoportokat, mint például a háromgenerációs háztartások.

2. táblázat: Elemszámok az Életünk fordulópontjai adatfelvétel mintájában (n számok)

\begin{tabular}{|l|c|c|c|c|c|}
\hline \multicolumn{1}{|c|}{25 év alatti gyermeket nevelő szülők } & $\mathbf{2 0 0 1}$ & $\mathbf{2 0 0 4}$ & $\mathbf{2 0 0 8}$ & $\mathbf{2 0 1 2}$ & $\mathbf{2 0 1 6}$ \\
\hline Gyermeket nevelő szülők összesen & 6365 & 5148 & 3891 & 4062 & 3060 \\
\hline Háromgenerációs háztartásban élő gyermekes szülők & 661 & 622 & 508 & 497 & 320 \\
\hline
\end{tabular}

Forrás: Életünk fordulópontjai adatfelvétel 2001, 2004, 2008, 2012 és 2016-os hulláma (1-5. hullám)

Megjegyzés: Az elemszámok azoknak a kérdezetteknek a számát jelölik, akik szülö státuszban voltak az adatfelvétel idôpontjában, és a háztartásban éló gyermekeik 0 és 24 év közöttiek voltak.

\section{Általános trendek}

Magyarországon az általunk vizsgált időszakban a háromgenerációs háztartások aránya alacsony, és csökkenő tendenciát mutat. Ez a csökkenés azonban a második világháború utáni időszakban viszonylag mérsékelt ütemű, ami abból adódik, hogy a multigenerációs háztartások aránya már a háborút követő egy-két évtizedben sem volt túlságosan magas. Az 1960-as népszámlálás adatai szerint a 3 millió 79 ezer háztartásból 322 ezer tartozott ebbe a kategóriába. Ők a háztartásoknak 11 százalékát tették ki (KSH 1963). 1980-ban mi 7,5 százalékot mértünk, ami 2016ra 3 százalékra csökkent, vagyis az 1980-as érték 39 százalékára (3. táblázat). A változások mögött strukturális okok is állnak. Ezek közül az egyik legfontosabb a demográfiai öregedés jelensége, vagyis az, hogy a gyermekek és a fiatalok aránya folyamatosan csökkent ezen időszak alatt. Ez maga után vonja a háromgenerációs 
háztartások arányának csökkenését, hiszen ha kevesebb a gyermekes család, akkor az összes háztartáson belül kisebb azoknak az aránya is, akik potenciálisan háromgenerációsok lehetnek. Ez az oka annak is, hogy ha a gyermekes családok körében vizsgáljuk a kérdést, akkor sokkal kisebb a csökkenés mértéke. 1980-ban a gyermekes családok 16, 2016-ban 9 százaléka élt ebben a formában. Ez esetben a 2016-os érték az 1980-asnak 56 százaléka (3. táblázat).

3. táblázat: Háromgenerációs háztartások aránya a gyermekes családok körében, 19802016 (\%)

\begin{tabular}{l|r|r|r|r|r}
\hline A háztartások különböző csoportjai & $\mathbf{1 9 8 0}$ & $\mathbf{1 9 9 0}$ & $\mathbf{2 0 0 1}$ & $\mathbf{2 0 1 1}$ & $\mathbf{2 0 1 6}$ \\
\hline Az összes háztartáson belül & 7,5 & 5,1 & 5,1 & 3,9 & 2,9 \\
\hline A gyermekes háztartásokon belül & 15,5 & 11,5 & 12,4 & 11,5 & 9,2
\end{tabular}

Forrás: Népszámlálás 1980, 1990, 2001, 2011 és Mikrocenzus 2016. Saját számítás.

Megjegyzés: Gyermekes háztartásnak azokat tekintjük, ahol legalább egy 24 éves vagy fiatalabb gyermek nevelkedik.

Ugyanakkor az a tény, hogy a csökkenés a gyermekes családokra vetítve is bekövetkezett, azt mutatja, hogy más okai is vannak annak, hogy ez az együttélési forma napjaink társadalmában kevésbé van jelen, mint akár 20-30 évvel ezelőtt. Ahogyan már korábban is említettük, gazdasági, kulturális, társadalompolitikai faktorok is szerepet játszhatnak abban, hogy ez bekövetkezett. Ezeket részben megérthetjük azáltal, ha megismerjük, hogy a multigenerációs háztartások arányának csökkenése hogyan zajlott időben, valamint társadalmi csoportok szerint.

Az elmúlt évtizedekben, 1980 és 2016 között az említett csökkenés nem volt egyenletes, hiszen az 1980 és 1990 közötti időszak erőteljes csökkenését az 1990-es években növekedés követte, 2000 után viszont tovább csökkent az arány. Kontrolladatok hiányában nehéz megítélni, hogy az 1990-es mérés mennyire reális. Tekintve, hogy a rendszerváltás utáni évek komoly gazdasági visszaesést jelentettek, hogy megjelent és 1997-re csúcsot döntött a munkanélküliség, hogy az aktív korú népességnek nagy tömegei váltak inaktívvá, és hogy a lakáspiac is jelentősen beszúkült, a népszámlálási mérések reális folyamatokat jelezhetnek. Egyben egyfajta igazolást adhatnak arra, hogy a gazdasági recessziók az együttélési formákra is hatnak. Az Egyesült Államokban és Kanadában megfigyeltekhez hasonlóan, ahol a gazdasági recessziók évei alatt jelentősen növekedett a háromgenerációs háztartásban élők aránya (Keene-Batson 2010; Pew Research Center 2010, 2011; Kreider-Ellis 2011; Battams 2017; Pilkauskas-Cross 2018).

A multigenerációs háztartások előfordulása nem független a bennük élő felnőttek társadalmi státuszától. Ha a társadalmi státuszt az iskolai végzettséggel közelítjük, akkor azt tapasztaljuk, hogy a felsőfokú végzettségű szülők körében lényegesen alacsonyabb ennek az együttélési formának az előfordulása, mint a nem diplomások 
körében. A társadalmi távolságok pedig időben növekedtek, nemcsak a diplomások és a nem diplomások között, hanem a közép- és alapfokú végzettségúek között is (2. ábra). Ebből arra lehet következtetni, hogy a háromgenerációs együttélési forma időben nézve egyre inkább összekapcsolódott az alacsonyabb társadalmi státusszal. Ez alapján feltételezhetjük, hogy a multigenerációs együttélési forma létrejöttének egyik legfontosabb oka maga a szegénység lehet. A diverzifikáció folyamata az 1990es években indult, amikor jól láthatóvá vált, hogy miközben a diplomások körében tovább folytatódott a háromgenerációs háztartások arányának csökkenése, addig a középfokú végzettségűek körében enyhe, az alapfokúak körében pedig kifejezetten erős növekedés történt (2. ábra).

2. ábra: Háromgenerációs háztartások aránya a szülők (középső generáció) iskolai végzettsége szerint

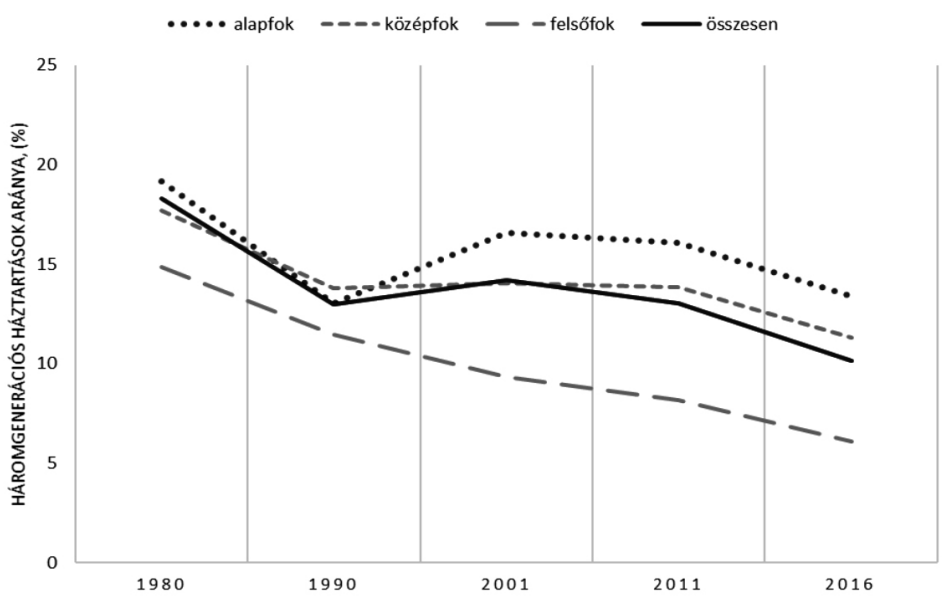

Forrás: Népszámlálás 1980, 1990, 2001, 2011 és Mikrocenzus 2016. Saját számítás.

Megjegyzés: A szülők iskolai végzettsége háztartásonként a magasabb végzettségü szülő legmagasabb iskolai végzettségét jelzi.

Az 1990-es évek abban a tekintetben is változást hoztak, hogy a szülők párkapcsolati státusza szerint hogyan alakult a háromgenerációs háztartások aránya. Miközben a párkapcsolaton alapuló családok körében 1990-ben és 2001-ben hasonló arányokat mértünk, az egyszülős családok esetében ugyanebben az időszakban erôs növekedésnek lehetünk szemtanúi (3. ábra). Ezáltal a különbség megnövekedett a két csoport között, amely a későbbi időszakban is fennmaradt. 
3. ábra: Háromgenerációs háztartások aránya a szülök (középső generáció) partnerkapcsolati státusza szerint

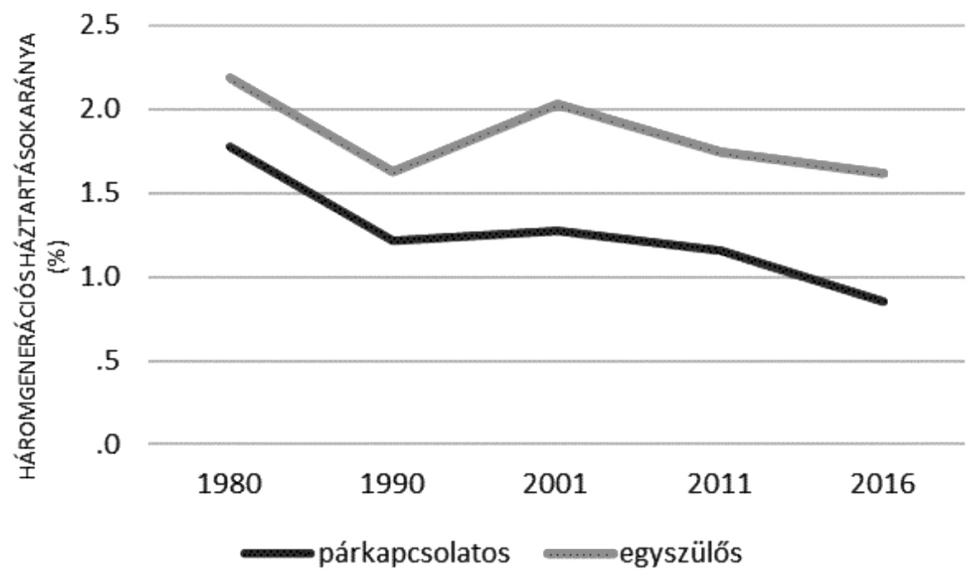

Forrás: Népszámlálás 1980, 1990, 2001, 2011 és Mikrocenzus 2016. Saját számítás.

\section{A háromgenerációs háztartások demográfiai és társadalmi meghatározottsága}

Ebben a fejezetben azt vizsgáljuk meg, hogy milyen egyéni és családi szintű demográfiai és szociológiai tényezők határozzák meg a multigenerációs együttélések kialakulását. Milyen változások történtek e vonatkozásban 1980 és 2016 között? Másrészt a 2016-os Mikrocenzus adatait elemezve a középső (szülői) generáció élettörténeti és a gyermekkori családi háttérre vonatkozó adatait is beemeltünk a magyarázó tényezők sorába. Feltételezhetjük ugyanis, hogy az, hogy valaki nem tud elköltözni a szülői házból, illetve az új család alapítása után vissza kell költöznie a szülőkhöz, a hátrányok hosszabb távú akkumulációjára utal: akár a tekintetben, hogy a szülők nem tudtak elegendő támogatást adni az önálló életkezdéshez, akár abban, hogy a gyermekek generációja - munkaerőpiaci problémák, demográfiai életesemények hatására - nem tudja megteremteni vagy fenntartani az önállósodás feltételeit.

Függő változónk azt mutatja, hogy a gyermekes család együtt él-e a nagyszülőkkel, vagy sem, azaz hogy háromgenerációs háztartásról beszélhetünk-e, vagy sem. A logisztikus regressziós elemzés demográfiai, társadalmi és térségi változók összefüggéseit mutatja a függő változónkkal. Ezáltal választ kaphatunk olyan kérdésekre, mint például hogy az iskolai végzettséggel akkor is összefügg-e a multigenerációs háztartás kialakulásának esélye, ha az iskolai végzettség szerinti különbségeket a térségi jellemzőkkel kontrolálljuk? Van-e ezekben a modellekben önálló hatása a térségi ismérveknek, azaz alapvető demográfiai és szociológiai jellemzők kontrollálása után is fennmaradnak-e 
a térségek (lakóhely jellege és regionális elhelyezkedése) szerinti differenciák? Választ kaphatunk arra is, hogy az egyszülős családoknak vajon azért nagyobb az esélye arra, hogy a nagyszülőkkel egy háztartásban éljenek, mert a válás feltételezhetően lakhatási problémákat, anyagi nehézségeket hozott az életükbe, vagy azért (is), mert az egyszülőssé válásban felülreprezentáltak az alacsonyabb végzettségúek.

A demográfiai változók arra utalhatnak, hogy ez az együttélési forma szorosan kapcsolódik egy-egy életszakaszhoz, életúteseményhez. A kétváltozós elemzések azt mutatják, hogy a gyermekek száma és a legfiatalabb gyermekek életkora fontos meghatározója a háromgenerációs családok kialakulásának. Az első gyermek vállalása, a kisgyermekes életkor a háromgenerációs együttélés esélyét növeli. Ez az összefüggés a többváltozós modellben is szignifikáns maradt, és mind az öt vizsgálati évben megfigyelhető. A gyermekszám és az életkor növekedésével fokozatosan csökken az esélye annak, hogy a gyermeket nevelő családok a nagyszülőkkel is együtt éljenek (4, 5. táblázat). E mögött feltételezhetően az az egyik magyarázat, hogy a gyermeket vállaló családok egy része nem tud a gyermekvállalás előtt vagy azzal közel egy időben elköltözni a szülői házból, de a későbbiekben megtörténik a szülői házból való elköltözés. Az időbeli hatásokat tekintve elmondhatjuk, hogy a gyermekek száma mindvégig szignifikáns hatással bír, de ez a hatás időben csökken. A legfiatalabb gyermek életkorát tekintve a 2000-es években megerősödött annak a hatása, hogy a gyermeket nevelő családban 0 és 3 év közötti gyermek él. 2001-ben és az azt követő években is több mint kétszeresére növelte a háromgenerációs háztartássá válás esélyét a referenciacsoporthoz képest, ha óvodáskor alatti gyermek is élt a családban. Ez azt mutatja, hogy a multigenerációs együttélési forma egyre inkább a gyermeki életpálya legelejéhez kapcsolódott.

Az egyszülős családokra vonatkozó korábbi kutatásainkban azt láttuk, hogy a gyermeküket egyedül nevelő szülők, főként nők körében viszonylag magas a nagyszülőkkel együtt élők aránya (Monostori 2021). Ennek oka lehet az, hogy azokban a háztartásokban, ahol több felnőtt generáció is él együtt, nagyobb a kapcsolatok törékenysége, amelyek felbomlása után a szülői generáció egyik tagja, jellemzően a férj /férfi partner elköltözik. Másrészt az is oka lehet ennek, hogy a válás vagy a partner elvesztése után a családok nehéz anyagi helyzetbe kerülnek, esetleg lakhatási problémáik vannak, és ezért visszaköltöznek a szülői házba. Az egyszülős családok magasabb esélye minden vizsgálati évben kimutatható volt a többváltozós modellekben is. A kétváltozós elemzések azt mutatják, hogy ez a hatás időben erősödik, de a többváltozós elemzés ezt nem erősítette meg (4, 5. táblázat). Ennek az volt az oka, hogy amikor az iskolai végzettség belépett a modellbe, akkor lényegesen csökkent a családszerkezeti hatás. Erős korreláció van tehát a szülők iskolai végzettsége és a családszerkezet között. Minél alacsonyabb valakinek az iskolai végzettsége, annál nagyobb az egyszülős családdá válás kockázata, és a kettő összekapcsolódásával rendkívüli módon felerősödik annak az esélye, hogy a gyermekes család együtt éljen a szülői generációval. 
$\mathrm{Az}$ iskolai végzettség a rendszerváltás utáni években a legerősebb differenciáló tényezőnek bizonyult. A háromgenerációs együttélési forma sokkal jellemzőbb az alacsonyan kvalifikált szülők családjaira, mint a magasabb végzettségűekre. Ráadásul időben az egyik legmarkánsabb változás az iskolai végzettség szerinti különbségek alakulásában zajlott. Miközben 1980-ban és 1990-ben a háromgenerációs háztartássá válás kockázata iskolai végzettség szerint szignifikáns, de nem nagyon erőteljes különbségeket mutatott, 2000-es években jelentőssé, a 2010-es években pedig meghatározóvá vált (4,5. táblázat). Az iskolai végzettségi szintek közötti legmeghatározóbb választóvonal a diplomások és a nem diplomások között van. A 2010-es években már az érettségizettek körében is 1,7-1,8-szoros esélye volt annak, hogy háromgenerációs háztartásban éljenek, a diplomásokhoz képest.

Az általunk használt adatbázisokban nem állnak rendelkezésre a szülők hoszszabb távú munkaerőpiaci státuszára vonatkozó adatok. Ez azért problémás, mert azt feltételezzük, hogy a munkaerőpiaci hátrányok hosszabb távú akkumulációja vezethet ahhoz, hogy a gyermekes család a nagyszülői generációval egy háztartásban éljen. Vizsgálni csak az aktuális munkaerőpiaci státuszt tudtuk, amely a kétváltozós elemzésekben azt mutatta, hogy ha egyik szülő sem kereső, vagy csak egy kereső van a gyermekes családban, akkor az szignifikánsan növeli a nagyszülős háztartás kialakulásának kockázatát.

A többváltozós modellben azonban ez a hatás megváltozik. Nem csak a hatás ereje, hanem az iránya is (4, 5. táblázat). Erre egyelőre nehéz magyarázatot találni.

A háromgenerációs háztartások előfordulásának jellegzetes térbeli mintázata van, hiszen szignifikánsan nagyobb eséllyel fordul elő a falvakban és a kisebb városokban, mint a megyeszékhelyeken és Budapesten. Leginkább a Dél-Dunántúlon, a Nyugat-Dunántúlon és Észak-Magyarországon fordul elő, de kifejezetten magas a közép-magyarországi régió fővároson kívül eső részeiben is (4., 5. táblázat). 
4. táblázat: A háromgenerációs együttéléseket meghatározó demográfiai és szociológiai jellemzők, kétváltozós összefüggések (logisztikus regresszió; esélyhányadosok)

\begin{tabular}{|c|c|c|c|c|c|c|c|c|c|c|}
\hline \multirow[b]{2}{*}{ Társadalmi ismérvek } & \multicolumn{2}{|c|}{1980} & \multicolumn{2}{|c|}{1990} & \multicolumn{2}{|c|}{2001} & \multicolumn{2}{|c|}{2011} & \multicolumn{2}{|c|}{2016} \\
\hline & $\operatorname{Exp}(B)$ & S.E. & $\operatorname{Exp}(B)$ & S.E. & $\operatorname{Exp}(B)$ & S.E. & $\operatorname{Exp}(B)$ & S.E. & $\operatorname{Exp}(B)$ & S.E. \\
\hline \multicolumn{11}{|l|}{ Gyermekek száma } \\
\hline 1 & 1,451 & 0,007 & 1,685 & 0,009 & 1,324 & 0,008 & 1,332 & 0,009 & 1,314 & 0,009 \\
\hline 2 & 1,207 & 0,008 & 1,328 & 0,009 & 1,059 & 0,008 & 1,110 & 0,009 & 1,028 & 0,010 \\
\hline 3 és több & \multicolumn{10}{|l|}{ Ref. } \\
\hline \multicolumn{11}{|c|}{ A legkisebb gyermek életkora } \\
\hline \begin{tabular}{l|l}
$0-3$ éves \\
\end{tabular} & 1,633 & 0,007 & 1,352 & 0,009 & 1,904 & 0,008 & 1,673 & 0,008 & 1.192 & 0,009 \\
\hline 4-5 éves & 1,273 & 0,009 & 1,173 & 0,011 & 1,587 & 0,010 & 1,436 & 0,011 & 1,104 & 0,012 \\
\hline 6-14 éves & 1,343 & 0,007 & 1,107 & 0,008 & 1,301 & 0,007 & 1,331 & 0,008 & 1,039 & 0,009 \\
\hline 15-18 éves & 1,212 & 0,009 & 1,072 & 0,010 & 1,145 & 0,009 & 1,162 & 0,010 & 1,045 & 0,011 \\
\hline \begin{tabular}{|l|l|}
$19-24$ éves \\
\end{tabular} & \multicolumn{10}{|l|}{ Ref. } \\
\hline \multicolumn{11}{|c|}{ A szülök generációjának párkapcsolati státusza } \\
\hline \begin{tabular}{l|l} 
Párkapcsolaton alapuló \\
\end{tabular} & \multicolumn{10}{|c|}{ Ref. } \\
\hline Gyermekét egyedül nevelő & 1,232 & 0,006 & 1,343 & 0,006 & 1,585 & 0,006 & 1,506 & 0,006 & 1,896 & 0,007 \\
\hline \multicolumn{11}{|l|}{ A szülök iskolai végzettsége } \\
\hline Általános iskola & 1,172 & 0,007 & ns. & & 1,615 & 0,008 & 1,929 & 0,009 & 2,178 & 0,011 \\
\hline Szakmunkásképző & 1,642 & 0,008 & 1,317 & 0,008 & 1,891 & 0,008 & 1,994 & 0,008 & 2,228 & 0,009 \\
\hline Érettségi & 1,194 & 0,008 & 1,203 & 0,007 & 1,509 & 0,008 & 1,698 & 0,008 & 1,866 & 0,008 \\
\hline \begin{tabular}{|l|l|} 
Diploma \\
\end{tabular} & \multicolumn{10}{|l|}{ Ref. } \\
\hline \multicolumn{11}{|c|}{ A szülök gazdasági aktivitása } \\
\hline \begin{tabular}{|l|l} 
Egyik sem kereső \\
\end{tabular} & ns. & & 1,044 & 0,010 & 1,412 & 0,007 & 1,598 & 0,007 & 1,351 & 0,010 \\
\hline Csak az egyik szülő kereső & ns. & & 1,167 & 0,005 & 1,301 & 0,005 & 1,302 & 0,006 & 1,100 & 0,006 \\
\hline Mindkét szülö kereső & \multicolumn{10}{|l|}{ Ref. } \\
\hline \multicolumn{11}{|l|}{ Településtípus } \\
\hline Budapest & 1,247 & 0,007 & 1,426 & 0,008 & 1,068 & 0,009 & 1,067 & 0,010 & 0,954 & 0,011 \\
\hline Megyeszékhely & \multicolumn{10}{|l|}{ Ref. } \\
\hline Egyéb város & 1,268 & 0,007 & 1,267 & 0,008 & 1,251 & 0,007 & 1,286 & 0,008 & 1,272 & 0,009 \\
\hline Falu & 2,172 & 0,006 & 2,106 & 0,007 & 1,789 & 0,007 & 1,692 & 0,008 & 1,686 & 0,009 \\
\hline \multicolumn{11}{|l|}{ Régió } \\
\hline Közép-Magyarország & 1,114 & 0,007 & 1,775 & 0,010 & 1,108 & 0,008 & 1,124 & 0,009 & 0,920 & 0,010 \\
\hline Észak-Alföld & \multicolumn{10}{|l|}{ Ref. } \\
\hline Dél-Alföld & $0,974^{* *}$ & 0,008 & ns. & & 0,928 & 0,010 & 0,850 & 0,011 & 0,801 & 0,012 \\
\hline Észak-Magyarország & 1,334 & 0,008 & 1,324 & 0,009 & 1,214 & 0,009 & 1,373 & 0,010 & 1,066 & 0,012 \\
\hline Közép-Dunántúl & 1,064 & 0,009 & 1,086 & 0,010 & 1,082 & 0,010 & 1,123 & 0,011 & 1,038 & 0,012 \\
\hline Dél-Dunántúl & 1,796 & 0,008 & 1,284 & 0,008 & 1,543 & 0,010 & 1,370 & 0,011 & 1,262 & 0,012 \\
\hline Nyugat-Dunántúl & 1,603 & 0,008 & 1,645 & 0,010 & 1,462 & 0,010 & 1,191 & 0,011 & 1,142 & 0,012 \\
\hline
\end{tabular}

Forrás: Népszámlálás 1980, 1990, 2001, 2011 és Mikrocenzus 2016

Megjegyzés: 1. Háztartási szintú adatok; 2. A táblázatban a szignifikanciaszinteket az alábbi módon jelöltük: ${ }^{*}<0,05$; ${ }^{* *} p<0,01$; amennyiben a megadott érték $P<0,001$, azt külön nem jelöltük. A nem szignifikáns hatásokat „ns.” jelzéssel jelöltük. 
5. táblázat: A háromgenerációs együttéléseket meghatározó demográfiai és szociológiai jellemzők, többváltozós összefüggések logisztikus regresszió; esélyhányadosok)

\begin{tabular}{|c|c|c|c|c|c|c|c|c|c|c|}
\hline \multirow[b]{2}{*}{ Társadalmi ismérvek } & \multicolumn{2}{|c|}{1980} & \multicolumn{2}{|c|}{1990} & \multicolumn{2}{|c|}{2001} & \multicolumn{2}{|c|}{2011} & \multicolumn{2}{|c|}{2016} \\
\hline & $\begin{array}{l}\text { Exp } \\
\text { (B) }\end{array}$ & S.E. & \begin{tabular}{c|} 
Exp \\
(B)
\end{tabular} & S.E. & \begin{tabular}{c|}
$\operatorname{Exp}$ \\
(B)
\end{tabular} & S.E. & $\begin{array}{l}\text { Exp } \\
\text { (B) }\end{array}$ & S.E. & $\begin{array}{c}\text { Exp } \\
\text { (B) }\end{array}$ & S.E. \\
\hline \multicolumn{11}{|l|}{ Gyermekek száma } \\
\hline 1 & 1,700 & 0,008 & 1,826 & 0,008 & 1,678 & 0,008 & 1,699 & 0,009 & 1,447 & 0,010 \\
\hline 2 & 1,259 & 0,008 & 1,358 & 0,009 & 1,252 & 0,009 & 1,317 & 0,009 & 1,135 & 0,010 \\
\hline 3 és több & \multicolumn{10}{|l|}{\begin{tabular}{|l|} 
Ref. \\
\end{tabular}} \\
\hline \multicolumn{11}{|l|}{ A legkisebb gyermek életkora } \\
\hline $0-3$ éves & 1,922 & 0,008 & 1,570 & 0,009 & 2,461 & 0,008 & 2,356 & 0,009 & 2,145 & 0,011 \\
\hline 4-5 éves & 1,583 & 0,010 & 1,311 & 0,011 & 1,959 & 0,010 & 1,894 & 0,011 & 1,550 & 0,013 \\
\hline 6-14 éves & 1,597 & 0,008 & 1,242 & 0,009 & 1,551 & 0,008 & 1,600 & 0,009 & 1,277 & 0,009 \\
\hline 15-18 éves & 1,340 & 0,009 & 1,149 & 0,010 & 1,255 & 0,009 & 1,275 & 0,010 & 1,127 & 0,011 \\
\hline 19-24 éves & \multicolumn{10}{|l|}{\begin{tabular}{|l|} 
Ref. \\
\end{tabular}} \\
\hline \multicolumn{11}{|c|}{ A szülök generációjának párkapcsolat státusza } \\
\hline Párkapcsolaton alapuló & \multicolumn{10}{|l|}{ Ref. } \\
\hline Gyermekét egyedül nevelő & 1,695 & 0,009 & 1,572 & 0,007 & 1,865 & 0,007 & 1,654 & 0,007 & 2,762 & 0,009 \\
\hline \multicolumn{11}{|l|}{ A szülők iskolai végzettsége } \\
\hline Általános iskola & 1,065 & 0,008 & 0,898 & 0,008 & 1,365 & 0,009 & 1,717 & 0,010 & 1,947 & 0,012 \\
\hline Szakmunkásképző & 1,346 & 0,008 & 1,169 & 0,008 & 1,685 & 0,008 & 1,982 & 0,008 & 2,119 & 0,009 \\
\hline Érettségi & 1,112 & 0,008 & 1,129 & 0,008 & 1,405 & 0,008 & 1,677 & 0,008 & 1,776 & 0,008 \\
\hline Diploma & \multicolumn{10}{|l|}{\begin{tabular}{|l|} 
Ref. \\
\end{tabular}} \\
\hline \multicolumn{11}{|l|}{ A szülök gazdasági aktivitása } \\
\hline Egyik sem kereső & 0,631 & 0,028 & 0,793 & 0,012 & 0,930 & 0,009 & ns. & & 0,538 & 0,013 \\
\hline Csak az egyik szülő kereső & 0,770 & 0,007 & 0,912 & 0,007 & 0,937 & 0,006 & 0,956 & 0,007 & 0,607 & 0,009 \\
\hline Mindkét szülő kereső & \multicolumn{10}{|l|}{ Ref. } \\
\hline \multicolumn{11}{|l|}{ Településtípus } \\
\hline Budapest & 1,298 & 0,010 & 1,355 & 0,012 & 0,938 & 0,012 & 0,862 & $\begin{array}{ll}0,012 \\
\end{array}$ & 0,857 & 0,014 \\
\hline Megyeszékhely & \begin{tabular}{|l|l} 
Ref. \\
\end{tabular} & & & & & & & & & \\
\hline Egyéb város & 1,388 & 0,007 & 1,369 & 0,008 & 1,260 & 0,008 & 1,219 & 0,009 & 1,217 & 0,010 \\
\hline Falu & 2,365 & 0,007 & 2,282 & 0,008 & 1,760 & 0,007 & 1,574 & 0,008 & 1,584 & 0,010 \\
\hline \multicolumn{11}{|l|}{ Régió } \\
\hline Közép-Magyarország & 1,153 & 0,009 & 1,245 & 0,010 & 1,336 & 0,010 & 1,409 & 0,010 & 1,205 & 0,011 \\
\hline Észak-Alföld & \multicolumn{10}{|l|}{ Ref. } \\
\hline Dél-Alföld & 0,971 & 0,008 & ns. & & 0,916 & 0,010 & 0,850 & 0,011 & 0,795 & 0,012 \\
\hline Észak-Magyarország & 1,205 & 0,008 & 1,163 & 0,010 & 1,140 & 0,009 & 1,292 & 0,010 & $\mathrm{~ns}$ & \\
\hline Közép-Dunántúl & 1,033 & 0,009 & 1,040 & 0,010 & 0,054 & 0,010 & 1,106 & 0,011 & ns & \\
\hline Dél-Dunántúl & 1,712 & 0,008 & 1,649 & 0,010 & 1,472 & 0,010 & 1,314 & 0,011 & 1,195 & 0,012 \\
\hline Nyugat-Dunántúl & 1,605 & 0,008 & 1,619 & 0,010 & 1,493 & 0,010 & 1,214 & 0,011 & 1,145 & 0,012 \\
\hline \multicolumn{11}{|l|}{ Modellstatisztikák: } \\
\hline Cox \& Snell Square & & |0,028 & & 0,020 & & 0,027 & & \begin{tabular}{|l|}
0,024 \\
\end{tabular} & & 0,024 \\
\hline Nagelkerke R Square & & 0,048 & & 0,038 & & 0,051 & & 0,046 & & 0,052 \\
\hline
\end{tabular}

Forrás: Népszámlálás 1980, 1990, 2001, 2011 és Mikrocenzus 2016

Megjegyzés: 1. Háztartási szintú adatok; 2. A táblázatban a szignifikanciaszinteket az alábbi módon jelöltük: ${ }^{*}<0,05$; ** $p<0,01$; amennyiben a megadott érték $P<0,001$, azt külön nem jelöltük. A nem szignifikáns hatásokat „ns." jelzéssel jelöltük.

2016-ra vonatkozóan a regressziós modellt további változókkal egészítettük ki. Ezáltal szerettünk volna élettörténeti adatokat is megvizsgálni. Elsőként a származási hatást mértük, hiszen a háromgenerációs háztartások kialakulásában szerepet játszhat az is, hogy a szülők nem tudják a gyerekeik családalapítását, önállósodását támogatni. Ehhez persze látni kellene a gyermeket vállaló párok mindkét tagjának származási hátterét, amire nincs módunk, de a kérdezettek származására utaló adatok is fontos hatásra mutathatnak rá. Másrészt ezeken az adatokon meg tudtuk vizsgálni azt is, hogy az életpályán előforduló munkanélküliség hogyan hat a multigenerációs háztartások kialakulására, és végül megvizsgáltuk az első gye- 
rekvállalás időzítésének hatását is. Ezek a modellek személyi szintű modellek. Kontrollváltozóként szerepeltettük mindazokat a változókat, amelyek az előző modellben is szerepeltek, de ezek hatását már nem foglaltuk a táblázatba (6. táblázat).

Származási változóként a kérdezett apjának iskolai végzettségét emeltük ki, amely szignifikánsan meghatározta a multigenerációs háztartások kialakulásának esélyét. A diplomás nagyszülők diplomás szülői generációhoz tartozó gyerekeihez képest az általános iskolai végzettségú nagyszülők gyerekeinek másfélszer, az érettségizetteknek közel 1,3-szor akkora esélye volt, hogy nagyszülős háztartásban éljen. Ugyancsak szignifikáns, bár az előzőnél jóval gyengébb hatása volt annak, hogy a kérdezett volt-e munkanélküli az életpályáján. A munkanélküliség megtapasztalása a szülői generáció bizonytalanabb munkaerőpiaci pozíciójára utal, bár nem tudjuk, mennyi ideig tartott a munkanélküliség, és milyen következményei voltak a család életére; tudta-e ezt kompenzálni a kérdezett partnerének kedvezőbb munkaerőpiaci helyzete, vagy sem. Végül azt vizsgáltuk meg, hogy az első gyermek vállalásának időpontja hogyan befolyásolja a háromgenerációs együttélés létrejöttét. A kétváltozós elemzés azt mutatta, hogy minél fiatalabban vállalja valaki az első gyermekét, annál nagyobb a valószínűsége annak, hogy a szülői házban éljen. Ezt azonban a többváltozós elemzés nem támasztotta alá, aminek az volt az oka, hogy a fiatalon szülővé válás alapvetően az alacsonyan kvalifikált csoportokra volt jellemző. Tehát az iskolai végzettség és a gyermekvállalás között erős korreláció állt fenn. Ebből arra következtethetünk, hogy nem önmagában a fiatalkori gyermekvállalás valószínűsíti a multigenerációs háztartás kialakulását, hanem az alacsony iskolai végzettség, amely növeli a korai gyermekvállalás esélyét is.

6. táblázat: A háromgenerációs együttéléseket meghatározó élettörténeti hatások, 2016 (logisztikus regresszió, esélyhányadosok)

\begin{tabular}{|c|c|c|}
\hline & & Kontrollált hatások \\
\hline & $\operatorname{Exp}(B)$ & S.E. \\
\hline \multicolumn{3}{|c|}{ Apa iskolai végzettsége a kérdezett gyermekkorában } \\
\hline Alapfok & 1,563 & 0,012 \\
\hline Érettségi & 1,321 & 0,013 \\
\hline \multicolumn{3}{|l|}{ Diploma } \\
\hline Nem volt édesapja/nem ismerte & 1,103 & 0,022 \\
\hline \multicolumn{3}{|c|}{ Volt-e munkanélküli az élete során? } \\
\hline Igen & 1,088 & 0,006 \\
\hline \multicolumn{3}{|l|}{ Nem } \\
\hline \multicolumn{3}{|l|}{ Mikor született az első gyermeke? } \\
\hline 20 éves kora előtt & 0,844 & 0,011 \\
\hline 20-24 éves korában & ns. & \\
\hline 25-29 éves korában & 1,161 & 0,007 \\
\hline \multicolumn{3}{|l|}{30 éves korában vagy később } \\
\hline \multicolumn{3}{|l|}{ Modellstatisztikák: } \\
\hline Cox \& Snell Square & 0,022 & \\
\hline Nagelkerke R Square & 0,050 & \\
\hline
\end{tabular}


Megjegyzés: 1. Személyi szintủ adatok. 2. A többváltozós modellben az összes változót szerepeltettük, ami a háztartási szintủ modellekben is benne volt (lásd 4. táblázat). 3. A táblázatban minden megadott érték p<0,001 szinten volt szignifikáns.

\section{Hogyan keletkeznek és mennyi ideig tartanak a háromgene- rációs együttélések?}

Ebben az alfejezetben azt vizsgáljuk meg, hogyan keletkezik és mennyi ideig tart az életpályán a multigenerációs együttélési forma. A nemzetközi kutatások általában azt találták, hogy nemcsak napjainkban, de még a korábbi évszázadokban is a fiatalok családalapítása utáni időszakra koncentrálódtak a háromgenerációs együttélések. Néhány év elteltével a háztartások nagy részében a generációk szétköltöztek egymástól, a fiatalok, elhagyva a szülői házat, új háztartást alapítottak. Ezek az esetek tehát tipikusan olyanok voltak, hogy a fiatalok nem a gyermekvállalás előtt, nem közvetlenül ahhoz kapcsolódóan, hanem néhány évvel azután hagyták el először a szülői háztartást. Keveset tudunk viszont arról, hogy vajon régen milyen gyakori volt a szülői házba való visszaköltözés. Előfordulhatott ez is, hiszen, ha a válások aránya alacsony is volt, sokan megözvegyültek, ami okozhatta azt, hogy valaki gyermekeivel együtt visszaköltözött a szülei háztartásába, így a háztartás háromgenerációssá vált. Mindezeknek a vizsgálatához napjainkban is olyan életpályaadatokra lenne szükségünk, amelyek bemutatják, hogy az egyének a különböző életszakaszaikban milyen szerkezetű háztartásban éltek. Ilyenek nem állnak rendelkezésre, de bizonyos kérdéseket meg tudunk válaszolni az Életünk fordulópontjai adatfelvétel alapján is, amely 2001 és 2016 között követi a kiválasztott egyének életét, és háromévenként felméri, hogy a kérdezettek milyen háztartásban élnek. Ráadásul az adatfelvétel a második hullámtól, 2004-től azt is feltérképezi, hogy a háztartásban élők mióta élnek együtt, pontosabban a kérdezett mióta él együtt a háztartás jelenlegi tagjaival. Az adatfelvétel elemszámai részletesebb, társadalmi rétegek, demográfiai csoportok szerinti vizsgálódást nem tesznek lehetővé, de néhány alapvető kérdés megválaszolására alkalmasak.

Az első ilyen kérdés, hogy a háromgenerációs háztartásokon belül mekkora azoknak az aránya, amelyek úgy keletkeztek, hogy a „középső generáció” el sem költözött a szülőktől, és mekkora azoké, amelyekben visszaköltözésről lehet beszélni. Számításaink során a háromgenerációs háztartásokból csak azokat tudtuk figyelembe venni, ahol a kérdezettek a szüleikkel élnek, hiszen, ha az apósukkal, anyósukkal élnek együtt, akkor nem tudjuk megmondani, hogy a párjuk, elköltözött-e valaha a szüleitől korábban, vagy sem. Az együttélés kezdetére vonatkozó információ ugyanis csak a kérdezett szemszögéből áll rendelkezésre. Az adatok alapján azt találtuk, hogy a szüleikkel is együtt élő kérdezettek körében minden vizsgált évben meghaladta az 50 százalékot, a 2010-es években a 60 százalékot is azoknak az aránya, akik még egyáltalán nem költöztek el a szülői házból (7. táblázat). Kérdéses, hogy mivel magyarázhatjuk ezt a növekedést. Lehetséges, hogy kapcsolódik ahhoz, hogy a 2010 körüli időszakban a gazdasági válság megnehezítette a fiatalok önállósodását, talán 
azokét is, akik már önálló családot alapítottak. Sajnos az alacsony esetszám nem teszi lehetővé, hogy további elemzések keretében az egyes csoportok demográfiai és szociológiai profilját is megrajzoljuk.

7. táblázat: A szüleikkel együtt élő középső generáció megoszlása aszerint, hogy mióta élnek a szülöi házban

\begin{tabular}{|l|r|r|r|r|} 
& \multicolumn{1}{|c|}{$\mathbf{2 0 0 4}$} & \multicolumn{1}{|c|}{$\mathbf{2 0 0 8}$} & \multicolumn{1}{c|}{$\mathbf{2 0 1 2}$} & \multicolumn{1}{c|}{$\mathbf{2 0 1 6}$} \\
\hline Születése óta (még nem költözött el a szülöi házból) & 54,3 & 57,2 & 63,2 & 63,7 \\
\hline Az első gyermeke születése előtt „költözött vissza” a szülői házba & 17,4 & 10,4 & 12,7 & 9,7 \\
\hline Az első gyermeke születése után „költözött vissza” a szülői házba & 28,3 & 32,4 & 24,1 & 26,6 \\
\hline Összesen & 100,0 & 100,0 & 100,0 & 100,0 \\
\hline N & 260 & 228 & 253 & 173
\end{tabular}

Megjegyzés: 1 . A táblázatban azok a szülők szerepelnek, akik 0 és 24 év közötti gyermeket nevelnek a saját háztartásukban. 2. Születése óta a szülőkkel élőknek azokat tekintettük, akik legalább az egyik szülőnél azt jelölték, hogy születésük óta egy háztartásban élnek vele.

Forrás: Életünk fordulópontjai 2-5. hulláma alapján saját számítás.

Megvizsgáltuk azt is, hogy mennyire tartós az életpályán a három generáció együttélése. Adataink egy 15 éves szakasz vizsgálatát tették lehetővé, de több rövidebb időtávot is kiemeltünk. Elemzésünkbe csak azok kerültek be, akiknek a háztartásában mindkét vizsgálati évben - a nyitó és a záró időpontban is - volt legfeljebb 24 éves gyermek. Ezek alapján azt mondhatjuk, hogy a gyermeket nevelő multigenerációs háztartások több mint 50, de kevesebb, mint 60 százaléka a négy évvel későbbi megfigyelési időpontban is nagyszülős háztartás volt. Nyolcéves időtávban a mutató értéke 40 és 50 százalék közé csökkent, majd a 12 éves időtartamban 40 százalék alá. 2001 és 2016 között, tehát a teljes 15 éves időszak alatt a 2001-ben háromgenerációsok háztartásoknak 30 százaléka minden megfigyelési évben az volt (8. táblázat). Mindezek elég dinamikus mozgást jeleznek a háromgenerációs együttélési formából való kilépésben. Az alacsony esetszám miatt azt nem vizsgáltuk, hogy hányan vannak azok, akik a köztes időszakban más háztartásszerkezetben is éltek.

8. táblázat: Háromgenerációs háztartásban maradók aránya az egyes évek között (paneladatok) (\%)

\begin{tabular}{c|c|c|c|c}
\multirow{2}{*}{ Évek } & \multicolumn{4}{|c}{ Háromgenerációs háztartásban maradók aránya t+3 ... 15 időpontban } \\
\cline { 2 - 5 } & $\mathbf{2 0 0 4}$ & $\mathbf{2 0 0 8}$ & $\mathbf{2 0 1 2}$ & $\mathbf{2 0 1 6}$ \\
\hline 2001 & 52,5 & 47,6 & 36,5 & 29,0 \\
\hline 2004 & & 58,7 & 42,3 & 31,6 \\
\hline 2008 & & & 55,9 & 41,9 \\
\hline 2012 & & & & 55,1
\end{tabular}

Megjegyzés: 1 . A táblázatban azok a szülők szerepelnek, akik mindkét megjelölt évben 0 és 24 év közötti gyermeket nevelnek a saját háztartásukban.

Forrás: Életünk fordulópontjai 1-5. hulláma alapján saját számítás. 


\section{Összegzés}

Tanulmányunkban a háromgenerációs együttélésekkel foglalkoztunk. Egy olyan együttélési formával, amiről a hétköznapi életben és a tudományos diskurzusokban is nagyon kevés szó esik. Ennek főként az az oka, hogy a háztartások körében viszonylag kis arányt tesznek ki azok, ahol unokák, szülők és nagyszülők együtt élnek. Számításaink ugyanakkor azt mutatják, hogy több mint 560 ezer ember él ilyen háztartásban, és bizonyos társadalmi csoportokban messze átlag feletti a reprezentációjuk. Ezek a csoportok általában több dimenzióban is társadalmi hátrányokkal írhatók le, illetve olyan életszakaszhoz, demográfiai eseményekhez kötődnek, amikor erőteljesebben jelennek meg anyagi nehézségek, munkaerőpiaci és lakhatási problémák.

A multigenerációs háztartások arányát egy társadalomban számos dolog befolyásolhatja. A makrotényezők némelyike hosszabb távon, míg mások rövid időszakra vonatkozóan fejtik ki a hatásukat. Az európai példák azt mutatják, hogy nagyon nehéz egyegy tényező konkrét hatását mérni, hiszen egyszerre több tényező is hat. Általában elmondhatjuk, hogy egy társadalom általános jóléti szintje befolyásolja a háromgenerációs háztartások arányát, hiszen a gazdagabb országokban kevesebb ilyen együttélési formát találunk. Ugyanakkor, ha az általános jóléti szint közvetlenül hatna erre a mutatóra, sokkal nagyobb különbségnek kellene lennie, például a nyugat-és a dél-európai országok között, illetve a kelet- és dél-európai mutatóknak sokkal közelebb kellene állniuk egymáshoz. A gazdasági recessziók hatását sem lehet mindenütt egyértelműen kimutatni, de például az USA-ban, az Egyesült Királyságban mérhető volt, és feltételezhetjük, hogy a hazai rendszerváltás és az azt követő gazdasági recesszió hatását lehet látni az 1990-es évek folyamataiban Magyarországon is, amikor összességében enyhén, bizonyos társadalmi csoportok - például az alacsonyan kvalifikált szülők vagy a gyermeküket egyedül nevelők - esetében erősebben növekedett a nagyszülős háztartások aránya. Kérdéses ugyanakkor az, hogy az 1990-es években felerősödő egyenlőtlenségek miért maradtak meg hosszabb távon. A gazdasági prosperitás időszakai miért nem eredményeznek ellentétes irányú tendenciákat? És kérdés marad az is, hogy egy kisebb és rövidebb ideig tartó recessziós időszak milyen hatással van a többgenerációs együttélések előfordulására. A 2009 körüli évek gazdasági válságának hatását nem látjuk az adatainkban, de lehetséges, hogy ennek csak az az oka, hogy nem elég sűrűek a megfigyelési időpontjaink.

A háromgenerációs háztartások arányát meghatározó makrofolyamatok közül mindenképpen ki kell emelnünk a társadalmak korstruktúrájának hatását. Ha egy társadalomban a gyermekek vagy éppen az idősek aránya relatíve alacsony, akkor kisebb a lehetősége annak, hogy ilyen együttélési formák elterjedjenek. Régebben az idősek, napjaink társadalmaiban inkább a gyerekek alacsonya aránya jelent egyfajta korlátot a háromgenerációs háztartások számának növekedésében. Ez az oka annak, hogy ha a háromgenerációs háztartásban élők arányát a gyermekek körében vizsgáljuk, akkor az elmúlt közel negyven évet tekintve mérsékeltebb csökkenést láthatunk, mint a teljes népességben.

Sajnos az adataink nem tették lehetővé, hogy a háromgenerációs háztartások demográfiai és szociológiai profiljának vizsgálatakor hálózatszerűen vizsgáljuk a fiata- 
labb és az idősebb generációk jellemzőit. Ezeknek az egyidejű vizsgálata tudna csak választ adni arra a kérdésre, hogy a vizsgált együttéléseket vajon a fiatalok vagy az idősek igényei/szükségletei motiválják-e erősebben. Ugyanakkor az a tény, hogy a fiatalok szemszögéből nézve ez az együttélési forma egyértelműen kapcsolódik össze a társadalmi hátrányok különböző dimenzióival, azt jelzi, hogy a fiatalok szükségleteinek meghatározó szerepe van a multigenerációs együttélések kialakulásában.

Az unokák, a szülők és a nagyszülők együttélése nem feltétlenül évtizedeken át tartó élethelyzet az egyéni életpályán. Erre a történeti demográfiai és a jelenkorra vonatkozó szakirodalom is felhívja a figyelmet. Ez utóbbi állítást azonban nagyon kevés szociológiai munka támasztja alá empirikusan is. A kérdéssel elsősorban amerikai kutatók foglalkoztak, főként abban a kontextusban, hogy a háromgenerációs háztartások instabilitása - ez esetben instabilitás alatt háztartásszerkezeti változásokat értenek - hogyan alakítja a gyermekfejlődés különböző aspektusait. A háromgenerációs együttélés életpályán belüli hosszát ezek a kutatások nagyon rövidre teszik, miközben az érintettség, vagyis az, hogy például egy gyermek a gyermekkorában legalább egyszer a nagyszüleivel és a szüleivel/szülöjével is együtt él, nagyon magas (Pilkauskas 2012; Oberlander et al. 2009; Beck-Beck 1984; 1989). Ráadásul bizonyos, elsősorban hátrányos helyzetű csoportokban, nagyon magas azoknak az aránya, akik többször be- és kilépnek a nagyszülői háztartásba (Oberlander et al. 2009). A mi adataink azt mutatják, hogy a háromgenerációs együttélésben való érintettség sokkal alacsonyabb, mint például az amerikai társadalomban, de azoknak az aránya, akik hosszabb ideig vannak ebben az együttélési formában, magasabb. Jelentős csoportot képviselnek azok is, akik nem visszaköltözők, hanem el sem tudnak költözni a szülői házból az önálló családalapítás után. Ebben nagy szerepet játszhat a magyar lakásállomány struktúrája is, amely alapvetően azon alapszik, hogy a lakásokban és házakban élők tulajdonosai, és nem bérlői az ingatlannak.

\section{Grandparents and grandchildren a common household. Multigenerational households in Hungary}

Abstract: The study deals with the households where grandchildren, parents and grandparents live under one roof. While the multigenerational households are relatively rare in the society, according to our estimation approximately 560 thousand people live in three-generational households in Hungary. Their proportion is determined by the general living standards of the society, social policies, the roots and characteristics of intergenerational solidarity, the demographic structure of the population and also by the attitudes towards the multigenerational co-residence. The share of multigenerational households didn't decrease such dynamically among the families with children between 1980 and 2016 than in the whole population. Since the smaller share of three generational households is partly caused by the decreasing proportion of children in the total population. In the course of time the three generational cohabiting more and more links up with social disadvantages, the lower qualification of parents, since the shrinking trends of the multigenerational households with low educated parent was not so remarkable. Moreover, the rate increased in the 1990th, during the economic recession. The multigenerational households are more frequent among the one-parent families, partly because after divorce or separation several parents move back into the parental house. This indicates that the multigenerational cohabiting links various life events up.

Keywords: multigenerational households, households with children, grandparents, grandchildren 


\section{Irodalom}

Albertini, M. - Kohli, M. - Vogel, C. (2007): Intergenerational Transfers of Time and Money in European Families: Common Patterns-Different Regimes? Journal of EuropeanSocialPolicy, 17(4):319-334.http://doi.org/10.1177/0958928707081068

Albuquerque, P. C. (2009): The elderly and the extended household in Portugal: an age-period - cohort analysis. Population Research and Policy Review, 28(3): 271289. http://doi.org/10.1007/s11113-008-9099-0

Albuquerque, P. C. (2011): Grandparents in multigenerational households: the case of Portugal. European Journal of Ageing, 8(3): 189-198.

http://doi.org/10.1007/s10433-011-0196-2

Andorka, R. (1996): Háztartási rendszerek és az idős emberek élete a 18-19. századi magyarországi falvakban. Aetas, 11.4: 128-156.

Aquilino, W. S. (1990): The likelihood of parent-adult child coresidence: Effects of family structure and parental characteristics. Journal of Marriage and the Family, 52(2), 405-419. https://doi.org/10.2307/353035

Battams, N. (2017): Sharing a Roof: Multi-generational Homes in Canada. (2016 Census Update) https://vanierinstitute.ca/sharing-a-roof-multi-generational-homesin-canada-2016-census-update/

Beck, S. H. - Beck, R. W. (1984): The formation of extended households during middle-age. Journal of Marriage and Family, 46(2), 277-287. http://doi.org/10.2307/352459

Beck, S. H. - Beck, R. W. (1989): The incidence of extended households among middleaged black and white women. Estimates from a 15 year panel study. Journal of Family Issues, 10(2): 147-168. http://doi.org/10.1177/019251389010002001

Bengtson, V. - Giarrusso, R. - Silverstein, M. - Wang, H. (2000): Families and Intergenerational Relationships in Ageing Societies. International Journal of Ageing, 2: 3-10. http://doi.org/10.2190/HA2.1.a

Bianchi, S. M. V. - Hotz, J. - McGarry, K. - Seltzer, J. A. (2007): Intergenerational Ties: Alternative Theories, Empirical Findings and Trends, and Remaining Challenges. California Center for Population Research On-line Working Paper Series. CCPR-024-06.

Boaz, R. F. - Hu, J. - Ye, Y. (1999): The Transfer of Resources from Middle-Ages Children to Functionally Limites Elderly Parents: Providing Time, Giving Money, Sharing Space. The Gerontologist, 39: 648-657.

http://doi.org/10.1093/geront/39.6.648

Choi, N. G. (2003): Coresidence between Unmarried Ageing Parents and Their Adult Children: Who Moved in With Whom and Why? Research on Ageing, 25: 384-404. http://doi.org/10.1177/0164027503025004003

Cohen, P. N. - Casper, L. M. (2002): In Whose Home? Multigenerational Families in the United States, 1999-2000. Sociological Perspectives, 45: 1-20.

http://doi.org/10.1525/sop.2002.45.1.1 
Coleman, M. - Ganong, L. (2008): Normative Beliefs About Sharing Housing with an Older Family Member. International Journal of Ageing and Human Development, 66: 49-72. http://doi.org/0.2190/AG.66.1.c

Eurofound (2019): Household composition and well-being. Publications Office of the European Union, Luxembourg.

Faragó, T. (2011): Bevezetés a történeti demográfiába. Budapest: Corvinus Egyetem.

Glaser, K. - Stuchbury, R. - Price, D. - Di Gessa, G. - Ribe, E. - Tinker, A. (2018): Trends in the prevalence of grandparents living with grandchild(ren) in selected European countries and the United States. European Journal of Ageing, 15: 237-250. http://doi.org/10.1007/s10433-018-0474-3.

Goldscheider, F. K. - Lawton, L. (1998): Family Experiences and the Erosion of Support for Intergenerational Coresidence. Journal of Marriage and the Family, 60: 623-632. http://doi.org/10.2307/353533

Harcsa, I. - Monostori J. (2012): Családi struktúrák az életciklusban. In Kolosi, T. Tóth, I. Gy. (szerk.): Társadalmi Riport 2012., TÁRKI, Budapest 65-92

Harcsa, I. - Monostori, J. (2018): A háztartás- és családszerkezeti változások hosszú távú trendjei Magyarországon európai kontextusban: teóriák, tévképzetek, tények. Demográfia, 60(4): 105-137. http://doi.org/10.21543/Dem.60.4.2.

Hareven, T. K. (1994): Ageing and Generational Relations: A Historical and Life Course Perspective. Annual Review of Sociology, Vol. 20, 437-461.

Hays, J. C. (2002): Living Arrangements and Health Status in Later Life: A Review of Recent Literature. Public Health Nursing, 19: 136-151.

http://doi.org/10.1046/j.1525-1446.2002.00209.x

Iacovou, M. - Skew, A. J. (2011): Household composition across the new Europe: Where do the new Member States fit in? Demographic Research 25(14):465-490. http://doi.org/ 10.4054/DemRes.2011.25.14

ILC (2012): Global Perspectives on Intergenerational Households and Relations. http://www.ilcfrance.org/images/upload/pages/annexe_5-Global_Alliance_ Intergenerational_Relations.pdf

Keene, J. R. - Batson, C. D. (2010): Under One Roof: A Review of Research on Intergenerational Coresidence and Multigenerational Households in the United States. Sociology Compass, 4/8. 642-657.

http://doi.org/10.1111/j.1751-9020.2010.00306.x

Kreider, R. - Ellis, R. (2011): Living arrangements of children: 2009. Current Population Reports, US Census Bureau.

KSH (1963): 1960. évi Népszámlálás 7. A családok és a háztartások adatai. KSH, Budapest KSH (2005): 2001. évi Népszámlálás. Nagyszülővel élő gyerekek. KSH, Budapest

Laslett, P. (1965): The World We Have Lost: England Before the Industrial Age. London: Routledge

Laslett, P. (1966): The Study of Social Structure From Listings of Inhabitants. In: Eversley, D. E. C. - Laslett, P. - Wrigley E. A. (1966): An Introduction to English 
Historical Demography. Cambridge Group for the History of Population and Social Structure, 1. London: Weidenfeld and Nicholson, 160-208.

Laslett, P. - Wall, R. (1972): Household and Family in Past Time. Cambridge: Cambridge University Press.

Laslett, P. (1983): Family and household as work group and kin group: areas of traditional Europe compared. In Wall, R. - Robin, J. - Laslett, P. (eds.): Family forms in historic Europe. Cambridge: Cambridge University Press, 513-563.

Liang, J. - Winchester J. B. - Krause, N.M. - Ofstedal, M. B. - Bennett, J. (2005): Health and living arrangements among older Americans: does marriage matter? Journal of Aging and Health, 17(3), 305-335. http://doi.org/10.1177/0898264305276300.

McGarry, K. - Schoeni, R. F. (2000): Social Security, Economic Growth, and the Rise in Independence of Elderly Widows in the 20th century. Demography, 37: 221-236. http://doi.org/10.2307/2648124

Mickus, M. - Stommel, M. - Given, C. W. (1997): Changes in Living Arrangements of Functionally Dependent Older Adults and Their Adult Children. Journal of Ageing and Health, 9: 126-143. http://doi.org/10.1177/089826439700900107

Monostori, J. (2021): A nagyszülők gondozási tevékenysége Magyarországon. Demográfia, 2020. 63.4: 319-355. http://doi.org/10.21543/DEM.63.4.2.

Nandy, S. - Selwyn, J. - Farmer, E. - Vaisey, P. (2011): Using Census Microdata to Examine the Extend and Nature of Kinship Care in the UK. Bristol: University of Bristol.

Oberlander, S. E. - Shebl, F. M. - Magder, L. S. - Black, M. M. (2009): Adolescent mothers leaving multi-generational households. Journal of Clinical Child and Adolescent Psychology, 38(1), 62-74. http://doi.org/10.1080/15374410802575321

Oravecz I. (2020): A rög gyermekei. I. Ondrok gödre. 341. o.

Pew Research Center (2010): The Return of the Multi-Generational Family Household.

Pew Research Center (2011): Fighting Poverty in a Tough Economy Americans Move in with Their Relatives. Washington D.C.

Piercy, K. W. (1998): Theorizing About Family Caregiving: The Role of Responsibility. Journal of Marriage and the Family, 60: 109-118. http://doi.org/10.2307/353445

Pilkauskas, N. V. (2012): Three-generation family households: differences by family structure at birth. Journal of Marriage and Family, 74(5): 931-943.

http://doi.org/10.1111/j.1741-3737.2012.01008.x

Pilkauskas, N. V. - Cross, C. (2018): Beyond the Nuclear Family: Trends in Children Living in Shared Households. Demography, 55:2283-2297. http://doi.org/10.1007/s13524-018-0719-y

Preoteasa, A. - Vlase, I. - Tufa, L. (2018): Intergenerational support as a reaction to socio-economic crisis: alteration of solidarity withon precarious Romanian households. European Societies, 20, 111-130.

http://doi.org/10.1080/14616696.2017.1402123 
Ruggles, S. (2003): Multigenerational families in nineteenth-century America. Continuity and Change, 18 (1), 2003, 139-165. http://doi.org/10.1017/S0268416003004466

Ruggles, S. (2007): The Decline of Intergenerational Coresidence in the United States, 1850 to 2000. American Sociological Review, 72. 964-989. http://doi.org/10.1177/000312240707200606

Saraceno, C. - Keck, W. (2010): Can we identify Intergenerational policy regimes in Europe? European Societies, 12, 675-696. http://doi.org/10.1080/14616696.2010.483006 Vasconcelos, P. (2003): Famílias complexas: tendências de evolução. Sociologia, problemas e práticas, 43: 83-96.

Verbist, G. - Diris, R. - Vandenbroucke, F. (2019): Solidarity between Generations in Extended Families: Old-Age Income as a Way Out of Child Poverty? European Sociological Review, 2020, Vol. 36. No. 2. 317-332. http://doi.org/10.1093/esr/jcz052.

Wall, K. (2004): Portugal. In Cizek B, Richter R (eds.): Families in the EU15 - Policies, challenges and opportunities. Vienna: Austrian Institute for Family Studies, 195-207.

Ward, R. A. - Logan, J. R. - Spitze, G. (1992): The Influence of Parent and Child Needs on Coresidence in Middle and Later Life. Journal of Marriage and the Family, 54: 209-221. http://doi.org/10.2307/353288

Ward, R. A. - Spitze, G. (2007): Nestleaving and Coresidence by Young Adult Children: the Role of Family. Research on Ageing, 29: 257-277. http://doi.org/10.1177/0164027506298225 